\title{
ARANOROSINOL A AND ARANOROSINOL B, TWO NEW METABOLITES FROM Pseudoarachniotus roseus: PRODUCTION, ISOLATION, STRUCTURE ELUCIDATION AND BIOLOGICAL PROPERTIES ${ }^{\dagger}$
}

\author{
Kirity Roy, E. K. S. Vijayakumar, Triptikumar Mukhopadhyay, \\ Sugata Chatterjee, R. G. Bhat, J. Blumbach \\ and Bimal N. Ganguli \\ Microbiology Department, Research Centre, Hoechst India Limited, \\ Mulund (W), Bombay-400 080, India \\ (Received for publication April 20, 1992)
}

\begin{abstract}
Two new secondary metabolites, aranorosinol A (1) and aranorosinol B (2), were isolated from a strain of Pseudoarachniotus roseus. Their structures were elucidated on the basis of their spectral properties and chemical transformations and were found to be similar to aranorosin (3) isolated from the same strain.
\end{abstract}

We have recently isolated two new metabolites, aranorosinol A (1) and aranorosinol B (2), from the fungal strain Y-30499 identified as Pseudoarachniotus roseus. Herein we report the isolation, structure elucidation and biological properties of these two metabolites. Compounds $\mathbf{1}$ and $\mathbf{2}$ are structurally related to aranorosin (3) which was isolated earlier from the same fungal $\operatorname{strain}^{1 \sim 3)}$.

\section{Fermentation}

Fermentation was carried out in shake flasks as well as in laboratory fermenters using the methods and conditions reported earlier ${ }^{1}$. The progress of the fermentation was monitored by the agar diffusion assay using Bacillus subtilis as the test strain. The antibiotics were present in both the culture filtrate and the mycelial cake.

\section{Isolation}

The culture filtrate ( 40 liters) was extracted with ethyl acetate $(2 \times 15$ liters $)$. The mycelial cake $(3.7 \mathrm{~kg})$

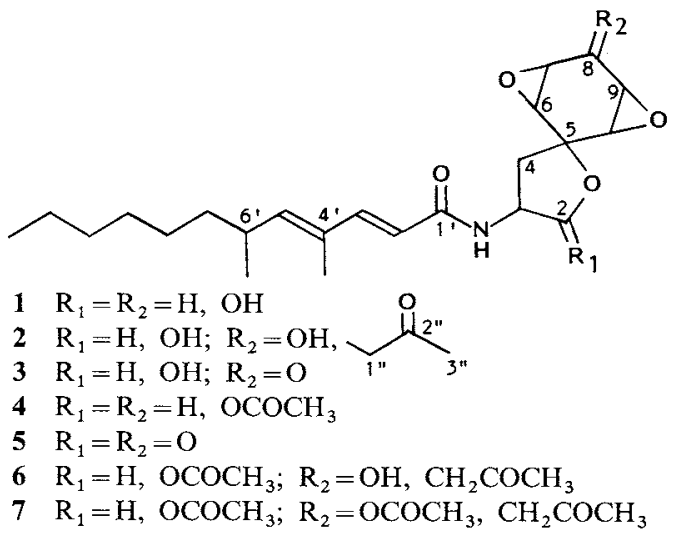

t Dedicated to Prof. Ch. Bhemasankara Rao of Andhra University on the occasion of his 60 th birthday. 
Table 1. Physico-chemical characteristics of aranorosinol A (1) and aranorosinol B (2).

\begin{tabular}{|c|c|c|}
\hline & Aranorosinol A & Aranorosinol B \\
\hline Nature & White powder & White powder \\
\hline MP & $133 \sim 135^{\circ} \mathrm{C}$ & $84 \sim 85^{\circ} \mathrm{C}$ \\
\hline Solubility & $\begin{array}{l}\mathrm{CH}_{2} \mathrm{Cl}_{2}, \mathrm{CHCl}_{3}, \text { EtOAc, acetone } \\
\text { and } \mathrm{MeOH}\end{array}$ & $\begin{array}{l}\mathrm{CH}_{2} \mathrm{Cl}_{2}, \mathrm{CHCl}_{3}, \text { EtOAc, acetone } \\
\text { and } \mathrm{MeOH}\end{array}$ \\
\hline$[\alpha]_{D}$ & $-25.06^{\circ}(c 7.82, \mathrm{MeOH})$ & $-9.3^{\circ}\left(c 0.4, \mathrm{CHCl}_{3}\right)$ \\
\hline TLC Rf & $0.38^{\mathrm{a}}, 0.13^{\mathrm{b}}$ & $0.55^{a}, 0.25^{b}$ \\
\hline FAB-MS (glycerol matrix) & $\begin{array}{l}422(\mathrm{M}+\mathrm{H})^{+}, 428(\mathrm{M}+\mathrm{Li})^{+} \\
\quad 444(\mathrm{M}+\mathrm{Na})^{+}\end{array}$ & $478(\mathrm{M}+\mathrm{H})^{+}$ \\
\hline Elemental Analysis & $\mathrm{C}_{23} \mathrm{H}_{35} \mathrm{NO}_{6} \cdot \mathrm{H}_{2} \mathrm{O}$ & $\mathrm{C}_{26} \mathrm{H}_{39} \mathrm{NO}_{7}$ \\
\hline Found: & C $62.45, \mathrm{H} 8.32, \mathrm{~N} 3.45$ & C 64.91, H 8.89, N 3.27 \\
\hline Calcd: & C 62.87, H 8.43, N 3.19 & C $65.40, \mathrm{H} 8.18, \mathrm{~N} 2.93$ \\
\hline $\mathrm{UV} \lambda_{\max }(\mathrm{MeOH}) \mathrm{nm}$ & 266 & 265 \\
\hline IR $(\mathrm{KBr}) \mathrm{cm}^{-1}$ & $\begin{array}{r}3400,1640,1600,1525,1440,1250 \\
1075,980,935,845,770 \text { and } 725\end{array}$ & $\begin{array}{l}3380,1720,1670,1630,1550,1460 \\
1280,1040,1000,935,900,860 \\
\text { and } 745\end{array}$ \\
\hline
\end{tabular}

a $\mathrm{CHCl}_{3}-\mathrm{MeOH}(85: 15)$.

b Ethyl acetate.

was extracted with acetone $(2 \times 8$ liters). The combined acetone extracts were concentrated under reduced pressure, diluted with water and extracted with ethyl acetate $(2 \times 750 \mathrm{ml})$. These ethyl acetate extracts of mycelial cake were combined with those of the culture filtrate and concentrated under reduced pressure to give $18.7 \mathrm{~g}$ of the crude antibiotic mixture as a reddish brown syrupy material. This was flash chromatographed on silica gel ( $230 \sim 400 \mathrm{mesh}, 250 \mathrm{~g}$, flow rate: $50 \mathrm{ml} / \mathrm{minute}$ ) using $\mathrm{CHCl}_{3}$ and a gradient of $\mathrm{MeOH}$ in steps of $1 \%$ for elution. A mixture of aranorosinol B (2) and aranorosin (3) was eluted with $2 \sim 3 \% \mathrm{MeOH}$ in $\mathrm{CHCl}_{3}$, while aranorosinol $\mathrm{A}(1)$ was eluted with $5 \% \mathrm{MeOH}$ in $\mathrm{CHCl}_{3}$.

The semipure aranorosinol A (1) (3.7 g) was flash chromatographed on silica gel $(230 \sim 400 \mathrm{mesh}$, $60 \mathrm{~g}$ ) with a flow rate of $40 \mathrm{ml} /$ minute using $\mathrm{CHCl}_{3}-\mathrm{MeOH}(95: 5)$ as the eluent. The active eluates were evaporated to dryness under reduced pressure, dissolved in $\mathrm{CHCl}_{3}$ and pure aranorosinol $\mathrm{A}(1)$ was precipitated as a white solid $(1.2 \mathrm{~g})$ by adding hexane. The mixture $(3.6 \mathrm{~g})$ of aranorosinol $\mathrm{B}(2)$ and aranorosin (3) was separated on a silica gel $(230 \sim 400$ mesh, $150 \mathrm{~g})$ column using petroleum ether $\left(60 \sim 70^{\circ} \mathrm{C}\right)$ - ethyl acetate mixtures for elution. Pure aranorosin (3) was eluted with petroleum ether - ethyl acetate $(1: 1)$, while aranorosinol $\mathbf{B}(2)$ was eluted with petroleum ether - ethyl acetate $(1: 3)$. The eluates containing 2 were evaporated to dryness, dissolved in $\mathrm{CHCl}_{3}$ and precipitated with hexane to give pure aranorosinol $\mathrm{B}$ as a white solid $(40 \mathrm{mg})$.

The physico-chemical characteristics of aranorosinol A (1) and aranorosinol B (2) are listed in Table 1.

\section{Structure Elucidation}

The ${ }^{1} \mathrm{H}$ and ${ }^{13} \mathrm{C}$ NMR data of aranorosinol A (1) and aranorosinol B (2) are listed in Table 2. A comparison of the ${ }^{1} \mathrm{H}$ and ${ }^{13} \mathrm{C}$ NMR spectra of aranorosinol A (1) and aranorosinol B (2) with those of aranorosin $(3)^{2,3)}$ showed close structural similarity of the compounds; all three compounds had the same fatty acid side chain (4,6-dimethyldodeca- $2 E, 4 E$-dienoyl moiety) and the same 1-oxaspiro[4.5]decane ring system. Structural differences between 1, 2 and 3 were observed at the C-8 position only.

Aranorosinol A (1)

Aranorosinol $\mathrm{A}(\mathbf{1}), \mathrm{C}_{23} \mathrm{H}_{35} \mathrm{NO}_{6}$, differs from 3 in having two additional hydrogens in the molecule. 
Table 2. ${ }^{13} \mathrm{C}$ and ${ }^{1} \mathrm{H}$ NMR data of aranorosinol A (1), aranorosinol B (2) and aranorosin (3).

\begin{tabular}{|c|c|c|c|c|c|c|}
\hline \multirow{2}{*}{ Position } & \multicolumn{3}{|c|}{${ }^{13} \mathrm{C}(\delta)^{\mathrm{a}}$} & \multicolumn{3}{|c|}{${ }^{1} \mathrm{H}(\delta \text {, Multiplicities, coupling constants in } \mathrm{Hz})^{\mathrm{b}}$} \\
\hline & $1^{\mathrm{c}}$ & $2^{d}$ & $3^{\mathrm{c}}$ & $\mathbf{1}^{\mathrm{e}}$ & $2^{\mathrm{c}}$ & $3^{\mathrm{c}}$ \\
\hline 2 & 96.55 & 96.65 & 96.60 & $5.54(\mathrm{~d}, 4.4)$ & $5.56(d, 4.5)$ & $5.63(\mathrm{~d}, 4.3)$ \\
\hline 3 & 52.73 & 52.44 & 52.00 & $4.68(\mathrm{~m})$ & $4.72(\mathrm{~m})$ & $4.80(\mathrm{~m})$ \\
\hline 4 & 37.35 & 37.05 & 35.90 & $\begin{array}{r}2.48\left(\mathrm{~m}, \mathrm{H}_{\mathrm{a}}\right) \\
1.98(\mathrm{dd}, 10.8 \\
\left.12.6, \mathrm{H}_{\mathrm{b}}\right)\end{array}$ & $\begin{array}{r}2.60(\mathrm{dd}, 8.5 \\
\left.12.8, \mathrm{H}_{\mathrm{a}}\right) \\
2.01(\mathrm{dd}, 10.8 \\
\left.12.8, \mathrm{H}_{\mathrm{b}}\right)\end{array}$ & $\begin{array}{r}2.65(\mathrm{dd}, 8.6 \\
\left.13.0, \mathrm{H}_{\mathrm{a}}\right) \\
2.06(\mathrm{dd}, \mathrm{I0.6} \\
\left.13.0, \mathrm{H}_{\mathrm{b}}\right)\end{array}$ \\
\hline 5 & 80.51 & 78.99 & 78.80 & - & - & - \\
\hline 6 & 61.41 & 59.59 & 64.40 & $3.44(\mathrm{~m})$ & $3.31(\mathrm{dd}, 3.4,3.7)$ & $3.68(\mathrm{dd}, 3.9,3.5)$ \\
\hline 7 & 57.18 & 58.19 & 55.80 & $3.44(\mathrm{~m})$ & $3.25(\mathrm{~m})$ & $3.44(\mathrm{dd}, 3.5,2.9)$ \\
\hline 8 & 64.15 & 66.42 & 198.40 & $4.28(\mathrm{t}, 2.7)$ & - & - \\
\hline 9 & 56.96 & 57.54 & 55.60 & $3.44(\mathrm{~m})$ & $3.25(\mathrm{~m})$ & $3.46(\mathrm{dd}, 3.5,2.9)$ \\
\hline 10 & 60.07 & 58.73 & 63.00 & $3.44(\mathrm{~m})$ & $3.25(\mathrm{dd}, 3.4,2.5)$ & $3.57(\mathrm{dd}, 3.9,3.5)$ \\
\hline $1^{\prime}$ & 167.31 & 166.87 & 167.00 & - & - & - \\
\hline $2^{\prime}$ & 118.01 & 117.89 & 117.00 & $5.85(\mathrm{~d}, 15.4)$ & $5.78(\mathrm{~d}, 15.4)$ & $5.77(\mathrm{~d}, 15.3)$ \\
\hline $3^{\prime}$ & 146.72 & 146.94 & 147.40 & $7.25(\mathrm{~d}, 15.4)$ & $7.24(\mathrm{~d}, 15.4)$ & $7.25(\mathrm{~d}, 15.3)$ \\
\hline $4^{\prime}$ & 131.23 & 131.11 & 130.80 & - & - & - \\
\hline $5^{\prime}$ & 147.69 & 147.69 & 148.50 & $5.68(\mathrm{~d}, 9.3)$ & $5.66(\mathrm{~d}, 9.7)$ & $5.67($ broad d) \\
\hline $6^{\prime}$ & 33.26 & 33.26 & 33.20 & $2.45(\mathrm{~m})$ & $2.49(\mathrm{~m})$ & $2.52(\mathrm{~m})$ \\
\hline $7^{\prime}$ & 37.38 & 37.38 & 37.20 & $1.26($ broad s) & 1.23 (broad s) & 1.27 (broad s) \\
\hline $8^{\prime}$ & 27.52 & 27.63 & 27.40 & $1.26($ broad s) & 1.23 (broad s) & $1.27($ broad s) \\
\hline $9^{\prime}$ & 29.47 & 29.58 & 29.40 & $1.26($ broad s $)$ & 1.23 (broad s) & 1.27 (broad s) \\
\hline $10^{\prime}$ & 31.85 & 31.96 & 31.80 & 1.26 (broad s) & 1.23 (broad s) & 1.27 (broad s) \\
\hline $11^{\prime}$ & 22.75 & 22.75 & 22.60 & $1.26($ broad s) & 1.23 (broad s) & 1.27 (broad s) \\
\hline $4^{\prime}-\mathrm{CH}_{3}$ & 12.56 & 12.57 & 12.40 & $1.79(\mathrm{~d}, 0.9)$ & $1.76(\mathrm{~d}, 1.0)$ & $1.78(\mathrm{~d}, 0.3)$ \\
\hline $6^{\prime}-\mathrm{CH}_{3}$ & 20.58 & 20.48 & 20.50 & $0.99(\mathrm{~d}, 6.7)$ & $0.97(\mathrm{~d}, 6.7)$ & $0.98(\mathrm{~d}, 6.7)$ \\
\hline $1^{\prime}-\mathrm{CH}_{3}$ & 14.08 & 14.08 & 14.10 & $0.89(\mathrm{t}, 6.5)$ & $0.87(\mathrm{t}, 6.5)$ & $0.88(t, 6.8)$ \\
\hline $2-\mathrm{OH}$ & - & - & - & 6.74 (broad s) $^{\mathrm{f}}$ & 5.54 (broad s) & 4.26 (broad s) \\
\hline $8-\mathrm{OH}$ & - & $-\ldots$ & - & $5.43($ broad s) & 4.69 (broad s) & - \\
\hline $\mathrm{NH}$ & - & - & $-\cdots$ & $6.63(\mathrm{~d}, 8.0)$ & $6.20(\mathrm{~d}, 8.3)$ & $6.09(\mathrm{~d}, 8.2)$ \\
\hline $1^{\prime \prime}$ & - & 47.45 & - & - & $3.07(\mathrm{~s})$ & - \\
\hline $2^{\prime \prime}$ & - & 210.44 & - & - & - & - \\
\hline $3^{\prime \prime}$ & - & 31.53 & - & - & $2.28(\mathrm{~s})$ & - \\
\hline
\end{tabular}

a Spectra were taken at $22.5 \mathrm{MHz}$ using $50 \mathrm{mg} / \mathrm{ml}$ concentrations and the assignments of 1 and 2 were based on comparison with those reported for aranorosin (3).

b Spectra were taken at $300 \mathrm{MHz}$ using $10 \mathrm{mg} / \mathrm{ml}$ concentrations.

c $\mathrm{CDCl}_{3}$.

d $\mathrm{CDCl}_{3}-\mathrm{C}_{6} \mathrm{D}_{6}(3: 1)$.

- $\mathrm{CDCl}_{3}-\mathrm{CD}_{3} \mathrm{OD}(8: 2)$.

f These chemical shifts were obtained from ${ }^{1} \mathrm{H}$ NMR spectrum taken in DMSO- $d_{6}$.

The ${ }^{1} \mathrm{H}$ NMR spectrum shows three $\mathrm{D}_{2} \mathrm{O}$ exchangeable protons $(\delta 6.74,6.63$ and 5.43$)$ as compared to the presence of two $\mathrm{D}_{2} \mathrm{O}$ exchangeable protons in 3 . This observation gave an early indication that 1 might be a reduced form of 3 .

The ${ }^{13} \mathrm{C}$ NMR data of 1 showed the absence of the C-8 carbonyl group of 3 and the presence of a new signal at $\delta 64.15(-\mathrm{CH}(\mathrm{O}) / \mathrm{DEPT}-135)$. In the ${ }^{1} \mathrm{H}$ NMR spectrum, this oxymethine proton appeared at $\delta 4.28(\mathrm{t}, J=2.7 \mathrm{~Hz})$. Acetylation of 1 with acetic anhydride - pyridine gave a diacetate $(4)\left(\mathrm{C}_{27} \mathrm{H}_{39} \mathrm{NO}_{8}\right.$, MP $184 \sim 186^{\circ} \mathrm{C}$, EI-MS: $\left.m / z 505\left(\mathrm{M}^{+} \cdot\right)\right)$ in which the $\mathrm{H}-8$ proton underwent a downfield shift of about $1 \delta$ to $\delta 5.36(\mathrm{t}, J=3 \mathrm{~Hz})$, as expected on acetylation of a secondary hydroxyl group. The other acetylated group in $\mathbf{4}$ was the hemiacetal group in which the H-2 proton appeared at $\delta 6.41$, a downfield 
shift of $0.9 \delta$ from its original position at $\delta 5.54$ in 1 . All these data indicated that aranorosinol A (1), instead of the $\mathrm{C}-8$ carbonyl group present in 3 , contained an $8-\mathrm{CH}(\mathrm{OH})$ moiety. This was further confirmed by chemical conversion of 3 to 1 . Thus, $\mathrm{NaBH}_{4}$ reduction of aranorosin (3) yielded a diastereoisomerically pure $\mathrm{C}-8$ alcohol which was identical by ${ }^{1} \mathrm{H} \mathrm{NMR}\left(300 \mathrm{MHz}, \mathrm{CDCl}_{3}-\mathrm{CD}_{3} \mathrm{OD}\right)$ to the naturally occurring alcohol aranorosinol A (1). Furthermore, Jones oxidation ${ }^{4)}$ of 1 gave a product which was identical (TLC, MP, IR, ${ }^{1} \mathrm{H}$ and ${ }^{13} \mathrm{C}$ NMR spectra) to the ketolactone $(5)^{2)}$ obtained by Jones oxidation of aranorosin (3). A chemical shift correlated $2 \mathrm{D}{ }^{1} \mathrm{H}^{-1} \mathrm{H}$ COSY spectrum of 1 recorded in DMSO- $d_{6}-\mathrm{D}_{2} \mathrm{O}$ mixture further confirmed the proton connectivities and the structure of aranorosinol A was thus established to be 1 .

Stereochemistry of $\mathbf{1}$ : The direct chemical conversion of $\mathbf{3}$ to $\mathbf{1}$ established the stereochemistry of all the protons in 1 except the H-8 proton. 2D NOESY as well as difference NOE data showed the expected cross-peaks, thus, confirming the stereochemistry of the diene system and also the epoxy protons. Furthermore, NOESY cross-peaks were observed between the $\mathrm{H}-8$ proton and the epoxy protons indicating their proximal orientation, but the exact relative configuration at $\mathrm{C}-8$ remains uncertain.

\section{Aranorosinol B (2)}

As in the case of 1 , aranorosinol $\mathrm{B}(2), \mathrm{C}_{26} \mathrm{H}_{39} \mathrm{NO}_{7}$, had three $\mathrm{D}_{2} \mathrm{O}$ exchangeable protons $(\delta 6.20$, 5.54 and 4.69), an oxygenated carbon signal at $\delta 66.42$ in the ${ }^{13} \mathrm{C}$ NMR spectrum and lacked the C-8 carbonyl group of 3 . In the ${ }^{13} \mathrm{C}$ NMR spectrum of 2 , three additional carbons appeared at $\delta 210.44$ (carbonyl group), $\delta 47.45\left(\mathrm{CH}_{2} / \mathrm{DEPT}-135\right)$ and $\delta 31.53\left(\mathrm{CH}_{3} / \mathrm{DEPT}-135\right)$. The $\mathrm{CH}_{2}$ and $\mathrm{CH}_{3}$ groups were isolated spin systems and appeared as singlets in the ${ }^{1} \mathrm{H}$ NMR spectrum at $\delta 3.07$ and $\delta 2.28$, respectively. The above data are best explained by an $8-\mathrm{C}(\mathrm{OH}) \mathrm{CH}_{2} \mathrm{COCH}_{3}$ moiety. The presence of such a group is known from the enaminomycins ${ }^{5)}$.

Aranorosinol B (2) underwent monoacetylation with acetic anhydride-pyridine (1.5 equiv, 24 hours at ambient temperature) to give $6, \mathrm{C}_{28} \mathrm{H}_{41} \mathrm{NO}_{8}$. It was characterised by the IR spectrum $\left(1755 \mathrm{~cm}^{-1}\right.$, $O$-acetyl) and the deshielding of the $\mathrm{H}-2$ proton from $\delta 5.56$ to 6.41 in the ${ }^{1} \mathrm{H}$ NMR spectrum. However, with excess of acetic anhydride - pyridine (5 equiv, 24 hours at ambient temperature) a mixture of 6 and a diacetate (7), in which the 8-hydroxyl group was also acetylated, was formed. These could be separated on a silica gel column $(230 \sim 400$ mesh $)$ using $\mathrm{CHCl}_{3}-\mathrm{MeOH}$ mixtures for elution.

The proposed structure of 2 had a $\beta$-hydroxycarbonyl group which was appropriate for a retroaldol condensation to give 3 . Reaction of 2 with butylamine (20 equiv) in DMSO ( 3 hours at ambient temperature) indeed gave a product which was identical to 3 by MP, TLC, IR, ${ }^{1} \mathrm{H}$ and ${ }^{13} \mathrm{C}$ NMR, thus establishing the structural relationships between 2 and 3. A $2 \mathrm{D}{ }^{1} \mathrm{H}^{-1} \mathrm{H}$ COSY spectrum of 2 further confirmed the proton connectivities and the structure of aranorosinol B was thus established to be 2 .
Table 3. MIC values of aranorosinol A (1) and aranorosinol B (2).

\begin{tabular}{lcc}
\hline & \multicolumn{2}{c}{$\begin{array}{c}\text { Minimum inhibitory } \\
\text { concentration }(\mu \mathrm{g} / \mathrm{ml})\end{array}$} \\
\cline { 2 - 3 } \multicolumn{1}{c}{ Test organisms } & Aranorosinol Aranorosinol \\
& $\mathrm{A}$ & $\mathrm{B}$ \\
\hline Staphylococcus aureus $209 \mathrm{P}$ & 15.6 & 31.25 \\
S. aureus 20240 & 31.25 & 15.62 \\
Bacillus subtilis & 3.9 & 15.62 \\
Streptococcus faecalis & 31.25 & 125.00 \\
Escherichia coli Ess 2231 & 62.5 & $>250.00$ \\
E. coli 9632 & $>250.00$ & $>250.00$ \\
Proteus vulgaris & $>250.00$ & $>250.00$ \\
Salmonella typhimurium & $>250.00$ & $>250.00$ \\
Klebsiella pneumoniae & $>250.00$ & $>250.00$ \\
Pseudomonas aeruginosa & $>250.00$ & $>250.00$ \\
Candida albicans & 62.5 & 250.00 \\
Saccharomyces cerevisiae & 31.25 & 250.00 \\
Aspergillus niger & $>250.00$ & $>250.00$ \\
Trichophyton mentagrophytes & 62.5 & $>250.00$ \\
Microsporum gypsetim & $>250.00$ & $>250.00$ \\
\hline
\end{tabular}


Stereochemistry of 2: Chemical conversion of 2 to 3 established the spatial relationships of the various protons in 2 to be the same as in 3 except at C-8. 2D NOESY and difference NOE experiments further supported this. NOESY cross-peaks were observed between the methylene protons $\mathrm{H}-1$ " and the epoxy protons $\mathrm{H}-7$ and $\mathrm{H}-9$ indicating that the $8-\mathrm{CH}_{2} \mathrm{COCH}_{3}$ group should be oriented close to the epoxy protons in the most favoured conformer of $\mathbf{2}$. However, the relative stereochemistry of the groups at C-8 remains uncertain.

\section{Biological Properties}

The minimum inhibitory concentrations (MIC) of aranorosinol A (1) and aranorosinol B (2) required to inhibit a variety of bacterial and fungal strains are listed in Table 3 . Both $\mathbf{1}$ and $\mathbf{2}$ possess only weak antibacterial and antifungal properties.

\section{Experimental}

UV spectra were recorded on a UVIKON 810 double beam spectrophotometer. IR spectra were taken on a Perkin-Elmer 157 spectrophotometer. Mass spectra were recorded on a Kratos MS 9025 spectrometer. Optical rotations were measured using a Perkin-Elmer 141 polarimeter. NMR spectra were recorded on Jeol FX90Q, Varian VXR 300 and Bruker ACP 300 instruments. DEPT, COSY and NOESY spectra were recorded using standard parameters. A mixing time of 500 milliseconds and $10 \mathrm{mmol}$ solutions of 1 and 2 in $\mathrm{CDCl}_{3}-\mathrm{CD}_{3} \mathrm{OD}$ and $\mathrm{CDCl}_{3}$ respectively were used for recording the NOESY spectrum. TLCs were carried out using pre-coated silica gel plates from E. Merck (for preparative TLC, Article No. 13794; for analytical TLC, Article No. 5554).

\section{Aranorosinol A Diacetate (4)}

To aranorosinol A (1) $(50 \mathrm{mg}, 0.12 \mathrm{mmol})$, acetic anhydride $(0.1 \mathrm{ml}, 1.06 \mathrm{mmol})$ and pyridine $(0.1 \mathrm{ml}$, $1.24 \mathrm{mmol}$ ) were added and the mixture kept at room temperature for 16 hours. The crude diacetate $(50 \mathrm{mg})$, obtained on usual work up, was purified by silica gel column chromatography $(230 \sim 400$ mesh, $5 \mathrm{~g}$ ) using $\mathrm{CHCl}_{3}-\mathrm{MeOH}$ mixtures for elution. The semi-pure diacetate was eluted with $1 \% \mathrm{MeOH}$ in $\mathrm{CHCl}_{3}$ and was further purified by preparative TLC using $\mathrm{CHCl}_{3}-\mathrm{MeOH}(95: 5)$ for developing the plates Pure aranorosinol A diacetate (4) was obtained as a white powder from $\mathrm{CHCl}_{3}$ - hexane mixture. Yield $40 \mathrm{mg}$; MP $184 \sim 186^{\circ} \mathrm{C}$; EI-MS $m / z 505\left(\mathrm{M}^{+} \cdot\right)$; UV $\lambda_{\max }(\mathrm{MeOH}) \mathrm{nm} 266$; IR $(\mathrm{KBr}) \mathrm{cm}^{-1} 3333,2924,1730$, $1718,1639,1603,1515,1361,1227,1111,1031,961,919,885$ and $778 ;{ }^{1} \mathrm{H} \mathrm{NMR}\left(90 \mathrm{MHz}, \mathrm{CDCl}_{3}, \mathrm{TMS}^{2}\right)$ $\delta 0.94\left(\mathrm{t}, J=6 \mathrm{~Hz}, \mathrm{CH}_{3}\right), 0.98\left(\mathrm{~d}, J=6 \mathrm{~Hz}, \mathrm{CH}_{3}\right), 1.24\left(\right.$ broad s, $\left.5 \times \mathrm{CH}_{2}\right), 1.76\left(\mathrm{~s}, \mathrm{CH}_{3}\right), 2.00(\mathrm{~m}, 2 \mathrm{H})$, $2.16\left(\mathrm{~s}, \mathrm{OCOCH}_{3}\right), 2.20\left(\mathrm{~s}, \mathrm{OCOCH}_{3}\right), 2.56(\mathrm{~m}, 1 \mathrm{H}), 3.23(\mathrm{~m}, 2 \mathrm{H}), 3.38(\mathrm{~m}, 2 \mathrm{H}), 4.92(\mathrm{~m}, 1 \mathrm{H}), 5.36(\mathrm{t}$, $J=3 \mathrm{~Hz}, 1 \mathrm{H}), 5.62($ broad d, $1 \mathrm{H}), 5.66\left(\mathrm{~d}, J=8 \mathrm{~Hz}, \mathrm{D}_{2} \mathrm{O}\right.$ exchangeable, $\left.\mathrm{NH}\right), 5.68(\mathrm{~d}, J=15 \mathrm{~Hz}, 1 \mathrm{H}), 6.41$ (d, $J=5 \mathrm{~Hz}, 1 \mathrm{H})$ and $7.22(\mathrm{~d}, J=15 \mathrm{~Hz}, 1 \mathrm{H}) .{ }^{13} \mathrm{C}$ NMR $\left(22.5 \mathrm{MHz}, \mathrm{CDCl}_{3}, \mathrm{TMS}\right) \delta 170.67(\mathrm{~s}), 169.48$ (s), 166.55 (s), 148.46 (d), 147.59 (d), 130.90 (s), 116.92 (d), 95.79 (d), 80.51 (s), 66.75 (d), 59.27 (d), 57.97 (d), $53.53($ d), 51.36 (d), $37.28(\mathrm{t}) .36 .08(\mathrm{t}), 33.27(\mathrm{~d}), 31.86(\mathrm{t}), 29.47(\mathrm{t}), 27.52(\mathrm{t}), 22.65(\mathrm{t}), 21.35(\mathrm{q})$, $20.91(\mathrm{q}), 20.48(\mathrm{q}), 14.09(\mathrm{q})$ and $12.57(\mathrm{q})$.

\section{Oxidation of Aranorosinol A (1) to the Ketolactone (5)}

To aranorosinol A (1) $(300 \mathrm{mg}, 0.71 \mathrm{mmol})$ in acetone $(10 \mathrm{ml})$, Jones reagent ${ }^{4)}(14 \mathrm{ml})$ was added slowly at room temperature over a period of 1 hour till the colour of the reagent persisted. The reaction mixture was then poured into ice water $(50 \mathrm{ml})$ and extracted with $\mathrm{CH}_{2} \mathrm{Cl}_{2}(3 \times 25 \mathrm{ml})$. The combined $\mathrm{CH}_{2} \mathrm{Cl}_{2}$ extracts were dried over $\mathrm{Na}_{2} \mathrm{SO}_{4}$ and evaporated under reduced pressure. The crude product (138 mg) was purified by preparative TLC using $\mathrm{MeOH}-\mathrm{CH}_{2} \mathrm{Cl}_{2}(10: 90)$ for developing the plates. The pure product $(95 \mathrm{mg})$ was identical to the ketolactone $(5)$ derived from the oxidation of aranorosin $(3)^{2)}$ by TLC, MP, IR, ${ }^{1} \mathrm{H}$ and ${ }^{13} \mathrm{C}$ NMR spectra.

Reduction of Aranorosin (3) to Aranorosinol A (1)

To aranorosin (3) (100 $\mathrm{mg}, 0.24 \mathrm{mmol})$ in THF $(5 \mathrm{ml})$, sodium borohydride $(9.4 \mathrm{mg}, 0.25 \mathrm{mmol})$ was 
added slowly at $-20^{\circ} \mathrm{C}$ and the mixture was stirred at $-20^{\circ} \mathrm{C}$ for 1 hour. The THF was removed under reduced pressure and the residue was dissolved in $\mathrm{CH}_{2} \mathrm{Cl}_{2}(20 \mathrm{ml})$, washed with water $(3 \times 15 \mathrm{ml})$ and the solvent removed under vacuum. The crude product $(75 \mathrm{mg})$ was purified by preparative TLC using $\mathrm{MeOH}-\mathrm{CH}_{2} \mathrm{Cl}_{2}$ (15:85) for developing the plates. The pure product $(40 \mathrm{mg})$ was identical to aranorosinol A (1) by TLC, MP, IR, ${ }^{1} \mathrm{H}$ and ${ }^{13} \mathrm{C}$ NMR spectra.

\section{Aranorosinol B Monoacetate (6)}

To aranorosinol B (2) $(48 \mathrm{mg}, 0.1 \mathrm{mmol})$ in $2 \mathrm{ml}$ of $\mathrm{CH}_{2} \mathrm{Cl}_{2}$, acetic anhydride $(15 \mu \mathrm{l}, 0.15 \mathrm{mmol})$ and pyridine $(15 \mu 1,0.18 \mathrm{mmol})$ were added and the mixture kept at room temperature for 24 hours. The crude product ( $45 \mathrm{mg}$ ), obtained on usual work up, was purified by preparative TLC using $\mathrm{CHCl}_{3}-\mathrm{MeOH}(95: 5)$ for developing the plates. The pure aranorosinol B monoacetate (6) was obtained as a white solid from $\mathrm{CHCl}_{3}$ - hexane mixture. Yield $35 \mathrm{mg}$; MP $83 \sim 85^{\circ} \mathrm{C}$; TLC Rf 0.43 (solvent $\mathrm{CHCl}_{3}-\mathrm{MeOH}$ (95: 5)); CI-MS $m / z 520(\mathrm{M}+\mathrm{H})^{+}$; molecular formula $\mathrm{C}_{28} \mathrm{H}_{41} \mathrm{NO}_{8}$; UV $\lambda_{\max }(\mathrm{MeOH}) \mathrm{nm} 264$; IR (KBr) cm ${ }^{-1} 3500,3380$, $3280,2985,2940,2860,1755,1715,1660,1620,1545,1380,1240,1075$ and $1015 .{ }^{1} \mathrm{H}$ NMR $(90 \mathrm{MHz}$, $\left.\mathrm{CDCl}_{3}, \mathrm{TMS}\right) \delta 0.98\left(\mathrm{t}, J=6.4 \mathrm{~Hz}, \mathrm{CH}_{3}\right), 1.01\left(\mathrm{~d}, J=5.4 \mathrm{~Hz}, \mathrm{CH}_{3}\right), 1.28\left(\right.$ broad s, $\left.5 \times \mathrm{CH}_{2}\right), 1.80\left(\mathrm{~s}, \mathrm{CH}_{3}\right)$, $2.14(\mathrm{~m}, 1 \mathrm{H}), 2.20\left(\mathrm{~s}, \mathrm{CH}_{3}\right), 2.32\left(\mathrm{~s}, \mathrm{OCOCH}_{3}\right), 2.50(\mathrm{~m}, 1 \mathrm{H}), 2.62(\mathrm{~m}, 1 \mathrm{H}), 3.08(\mathrm{~s}, 2 \mathrm{H}), 3.24(\mathrm{~m}, 4 \mathrm{H})$, $4.85(\mathrm{~m}, 1 \mathrm{H}), 5.60\left(\mathrm{~d}, J=7.2 \mathrm{~Hz}, \mathrm{D}_{2} \mathrm{O}\right.$ exchangeable), $5.65(\mathrm{~d}, J=9 \mathrm{~Hz}, 1 \mathrm{H}), 5.68(\mathrm{~d}, J=15 \mathrm{~Hz}, 1 \mathrm{H}), 6.41$ $\left(\mathrm{d}, J=4.5 \mathrm{~Hz}\right.$ ) and $7.21(\mathrm{~d}, J=15 \mathrm{~Hz}, 1 \mathrm{H}) .{ }^{13} \mathrm{C} \mathrm{NMR}\left(22.5 \mathrm{MHz}, \mathrm{CDCl}_{3}, \mathrm{TMS}\right) \delta 210.65(\mathrm{~s}), 169.26(\mathrm{~s})$, 166.54 (s), 148.45 (d), 148.12 (d), 130.90 (s), 116.92 (d), 95.90 (d), 80.51 (s), 66.42 (s), 58.62 (d), 58.29 (d), $57.97(\mathrm{~d}), 56.99$ (d), 51.36 (d), $47.35(\mathrm{t}), 37.27(\mathrm{t}), 36.62(\mathrm{t}), 33.26(\mathrm{~d}), 31.85(2 \times \mathrm{q}), 29.47(\mathrm{t}), 27.52(\mathrm{t})$, $22.64(\mathrm{t}), 21.34(\mathrm{t}), 20.48(\mathrm{q}), 14.08(\mathrm{q})$ and $12.56(\mathrm{q})$.

\section{Aranorosinol B Diacetate (7)}

To aranorosinol B (2) $(150 \mathrm{mg}, 0.31 \mathrm{mmol})$, pyridine $(0.2 \mathrm{ml}, 2.47 \mathrm{mmol})$ and acetic anhydride $(0.3 \mathrm{ml}$, $3.18 \mathrm{mmol}$ ) were added and the mixture kept at room temperature for 24 hours. The crude product, obtained on usual work up, was a mixture of mono- and di-acetates which was separated by silica gel column chromatography (230 400 mesh) using $\mathrm{CHCl}_{3}-\mathrm{MeOH}$ mixtures for elution.

The diacetate (7), eluted with $0.5 \% \mathrm{MeOH}$ in $\mathrm{CHCl}_{3}$, was obtained as a white solid from $\mathrm{CHCl}_{3}$ - hexane mixture. Yield $40 \mathrm{mg}$; MP $85 \sim 88^{\circ} \mathrm{C}$; TLC Rf 0.6 (solvent $\mathrm{CHCl}_{3}-\mathrm{MeOH}(95: 5)$ ); molecular formula $\mathrm{C}_{30} \mathrm{H}_{43} \mathrm{NO}_{9}$; CI-MS m/z $562(\mathrm{M}+\mathrm{H})^{+}$; UV $\lambda_{\max }(\mathrm{MeOH}) \mathrm{nm} 264$; IR $(\mathrm{KBr}) \mathrm{cm}^{-1} 3500,3400,3280,2960$, $2860,1750,1655,1620,1540,1380,1245,1070,1018$ and $860 .{ }^{1} \mathrm{H} \mathrm{NMR}\left(90 \mathrm{MHz}, \mathrm{CDCl}_{3}, \mathrm{TMS}\right) \delta 0.97$ (t, $\left.J=6.4 \mathrm{~Hz}, \mathrm{CH}_{3}\right), 1.01\left(\mathrm{~d}, J=5.4 \mathrm{~Hz}, \mathrm{CH}_{3}\right), 1.29\left(\right.$ broad s, $\left.5 \times \mathrm{CH}_{2}\right), 1.80\left(\right.$ broad s, $\left.\mathrm{CH}_{3}\right), 2.04(\mathrm{~m}, 1 \mathrm{H})$, $2.12\left(\mathrm{~s}, \mathrm{OCOCH}_{3}\right), 2.17\left(\mathrm{~s}, \mathrm{CH}_{3}\right), 2.27\left(\mathrm{~s}, \mathrm{OCOCH}_{3}\right), 2.48(\mathrm{~m}, 1 \mathrm{H}), 2.88(\mathrm{~m}, 1 \mathrm{H}), 3.20(\mathrm{~s}, 2 \mathrm{H}), 3.22(\mathrm{~m}$, $2 \mathrm{H}), 3.46(\mathrm{~m}, 2 \mathrm{H}), 4.90(\mathrm{~m}, 1 \mathrm{H}), 5.59\left(\mathrm{~d}, J=7 \mathrm{~Hz}, \mathrm{D}_{2} \mathrm{O}\right.$ exchangeable, $\left.\mathrm{NH}\right), 5.64(\mathrm{~d}, J=9 \mathrm{~Hz}, 1 \mathrm{H}), 5.68$ $(\mathrm{d}, J=15 \mathrm{~Hz}, 1 \mathrm{H}), 6.42(\mathrm{~d}, J=4.5 \mathrm{~Hz}, 1 \mathrm{H})$ and $7.22(\mathrm{~d}, J=15 \mathrm{~Hz}, 1 \mathrm{H}) \cdot{ }^{13} \mathrm{C}$ NMR $\left(22.5 \mathrm{MHz}, \mathrm{CDCl}_{3}\right.$, TMS) $\delta 203.61(\mathrm{~s}), 169.79(\mathrm{~s}), 168.93(\mathrm{~s}), 166.33(\mathrm{~s}), 148.34$ (d), 147.58 (d), 130.79 (s), 116.70 (d), 95.57 (d), $80.51(\mathrm{~s}), 59.70(\mathrm{~s}), 57.32(4 \times \mathrm{d}), 51.25(\mathrm{~d}), 46.92(\mathrm{t}), 37.81(\mathrm{t}), 37.27(\mathrm{t}), 33.26(\mathrm{~d}), 31.85(\mathrm{q}), 31.42(\mathrm{q})$, $29.36(\mathrm{t}), 27.41(\mathrm{t}), 22.64(\mathrm{t}), 21.34(\mathrm{t}), 20.48(\mathrm{q}), 13.97(\mathrm{q})$ and $12.46(\mathrm{q})$.

The pure monoacetate $(65 \mathrm{mg})$, eluted with $1 \% \mathrm{MeOH}$ in $\mathrm{CHCl}_{3}$, was identical to 6 by TLC and ${ }^{1} \mathrm{H}$ NMR spectrum.

\section{Conversion of Aranorosinol B (2) to Aranorosin (3)}

To aranorosinol B (2) $(500 \mathrm{mg}, 1.05 \mathrm{mmol})$ in dry DMSO $(10 \mathrm{ml})$, dry butylamine $(2 \mathrm{ml}, 20.2 \mathrm{mmol})$ was added dropwise with stirring. The resultant pale yellow solution was stirred at room temperature for 38 hours. The crude product $(270 \mathrm{mg})$, obtained on usual work up, was chromatographed on silica gel (230 400 mesh) using $\mathrm{CHCl}_{3}-\mathrm{MeOH}$ mixtures for elution. The semi-pure product was further purified by preparative TLC using ethyl acetate for developing the plates. The pure product was identical to aranorosin (3) by TLC, UV, IR, ${ }^{1} \mathrm{H}$ and ${ }^{13} \mathrm{C}$ NMR and CI-MS spectra.

\section{Acknowledgments}

We thank Dr. P. K. INAMDAR of Hoechst India Limited for elemental analyses and recording some of the spectra. We thank Dr. H. W. FehlHaber of Hoechst AG for his valuable comments and for recording some of the spectra. We 
gratefully acknowledge the $300 \mathrm{MHz}$ NMR facility of the Regional Sophisticated Instrumentation Centre (R.S.I.C.), Bombay, India. The technical assistance of Ms. BERNICE SMITH is acknowledged.

\section{References}

1) Roy, K.; T. Mukhopadhyay, G. C. S. Reddy, K. R. Desikan, R. H. Rupp \& B. N. Ganguli: Atanorosin, a novel antibiotic from Pseudoarachniotus roseus. I. Taxonomy, fermentation, isolation, chemical and biological properties. J. Antibiotics 41: 1780 1784, 1988

2) Fehlhaber, H.-W.; H. Kogler, T. Mukhopadhyay, E. K. S. Vujayakumar, K. Roy, R. H. Rupp \& B. N. GANGUli: Aranorosin, a novel antibiotic from Pseudoarachniotus roseus. II. Structure elucidation. J. Antibiotics 41: $1785 \sim 1794,1988$

3) Fehlhaber, H. W; H. Kogler, T. Mukhopadhyay, E. K. S. Vijayakumar \& B. N. Ganguli: Structure of aranorosin, a new antibiotic of a novel skeletal type. J. Am. Chem. Soc. 110: 8242 8243, 1988

4) Bowers, A.; T. G. HAlsall, E. R. H. Jones \& (in part) A. J. LemiN: The chemistry of the triterpenes and related compounds. Part XVIII. Elucidation of the structure of polyporenic acid C. J. Chem. Soc. 1953: 2548 2560, 1953

5) Itoh, Y.; T. Haneishi, M. Arai, T. Hata, K. Aiba \& C. Tamura: New antibiotics, enaminomycins A, B and C. III. The structures of enaminomycins A, B and C. J. Antibiotics 31: 838 846, 1978 